\title{
Flavanols from Japanese quince (Chaenomeles japonica) fruit suppress expression of cyclooxygenase-2, metalloproteinase-9, and nuclear factor-kappaB in human colon cancer cells
}

\author{
Katarzyna Owczarek', Elżbieta Hrabec², Jakub Fichna', Dorota Sosnowska³, \\ Maria Koziołkiewicz ${ }^{3}$, Jacek Szymański ${ }^{4}$ and Urszula Lewandowska1 ${ }^{\circledR}$
}

1Department of Biochemistry, Faculty of Medicine, Medical University of Lodz, Łódź, Poland; 2Department of Medical Enzymology, Faculty of Medicine, Medical University of Lodz, Łódź, Poland; ${ }^{3}$ nstitute of Technical Biochemistry, Faculty of Biotechnology and Food Sciences, Lodz University of Technology, Łódź, Poland; ${ }^{4}$ Central Scientific Laboratory, Faculty of Health Sciences, Medical University of Lodz, Łódź, Poland

\begin{abstract}
Natural polyphenols and polyphenol-rich extracts have been found to possess preventive and therapeutic potential against several types of cancers, including colorectal cancer (CRC), which is an example of an inflammation-associated cancer. This study examines the chemopreventive effect of a Japanese quince (Chaenomeles japonica) fruit flavanol preparation (JQFFP) on colon cancer SW-480 cells. JQFFP, rich in procyanidin monomers and oligomers, was found to inhibit the SW-480 cell viability by $40 \%$ at $150 \mu \mathrm{M}$ catechin equivalents (CE) after $72 \mathrm{~h}$ incubation when compared to control, but it was non-toxic to normal colon fibroblast CCD-18Co cells. Furthermore, $100 \mu \mathrm{M}$ CE JQFFP suppressed COX-2 mRNA expression to $36.7 \%$ of control values and protein expression to $77 \%$. In addition, JQFFP reduced the MMP-9 protein expression (to $24 \%$ vs. control at $100 \mu \mathrm{M}$ CE) and caused inhibition of its enzymatic activity (to $35 \%$ vs. control at $100 \mu \mathrm{M}$ CE). Not only did JQFFP inhibit the COX-2 and MMP-9 levels, but it also reduced the NF-KB protein expression (to $65 \%$ of control) and phosphorylation of its p65 subunit (to $51 \%$ ) at $100 \mu \mathrm{M} \mathrm{CE}$. These results provide the first evidence that JQFFP inhibits COX-2, MMP-9, and NF-KB expression, suggesting that it has cytotoxic, anti-inflammatory, and anti-metastatic activities towards the colon cancer SW-480 cells.
\end{abstract}

Key words: flavanols, Japanese quince (Chaenomeles japonica), colon cells, COX-2, MMP-9, NF-kB

Received: 26 April, 2017; revised: 05 July, 2017; accepted: 10 July, 2017; available on-line: 09 August, 2017

e-mail: urszula.lewandowska@umed.lodz.pl

Abbreviations: JQFFP, Japanese quince fruit flavanol preparation $\mathrm{CE}$, catechin equivalents; COX-2, cyclooxygenase-2; NF-KB, nuclear factor-kappaB; MMPs, matrix metalloproteinases; NSAIDs, non-steroidal anti-inflammatory drugs

\section{INTRODUCTION}

Plants constitute an important source of biologicallyactive compounds in foods which promote health and proper functioning of the organism, such as polyphenols, phytosterols, carotenoids, phospholipids, saturated and unsaturated fatty acids (Afrin et al., 2016). Research carried out in recent years indicates that natural polyphenols and polyphenol-rich extracts isolated from edible and therapeutic plants exhibit anti-inflammatory actions towards various cells, including human colon cancer cells. By modulating some signal transduction pathways, they can act as anti-inflammatory agents (Qian et al., 2015). Phenolic compounds could modulate the activities of some enzymes and other functional proteins which are involved in the inflammatory process (Shanmugam et al., 2011; Mitjavila \& Moreno, 2012). Among molecular targets of anti-inflammatory agents are cyclooxygenase-2 (COX-2) and nuclear factor-kappaB (NF-xB) (Shanmugam et al., 2011; Tak \& Firestein, 2001).

COX-2 catalyzes conversion of arachidonic acid to pro-inflammatory mediators, such as prostaglandins (in particular prostaglandin $\mathrm{E}_{2}$ ), which act as critical secondmessengers for immune processes, and stimulate various malignancies, such as colorectal carcinogenesis (Wang \& Dubois, 2010; Dixon et al., 2013). Up-regulation of COX-2, and, consequently, prostaglandin $\mathrm{E}_{2}$, may be involved in the invasion and metastasis of colorectal cancer cells by stimulating expression of the matrix metalloproteinases (MMPs), which play a key role in the degradation of the extracellular matrix (ECM) (Kessenbrock et al., 2010). Moreover, aberrant or increased expression of COX-2 has been widely implicated in the pathogenesis of many cancer types including colorectal cancer (CRC) (Park et al., 2014). Increased expression of COX-2 has been found in both, premalignant and malignant colorectal tumors, than in the normal intestinal mucosa, and high levels of COX-2 have been associated with decreased cancer patient survival (Wang et al., 2010). Transcriptional upregulation of the COX-2 gene expression can be induced by various signaling pathways (Temraz et al., 2013). It has been reported that the promoter region of the COX-2 gene contains a number of sequences that specifically bind several transcriptional factors, including nuclear factor- $x \mathrm{~B}(\mathrm{NF}-x \mathrm{~B})$ (Tazawa et al., 1994).

$\mathrm{NF}-x \mathrm{~B}$, a transcription factor of the Rel/NF- $x \mathrm{~B}$ family, comprised of a p50/p65 heterodimer, may control expression of genes whose proteins regulate many important cellular processes, such as inflammation, immune reactions, apoptosis, metastasis, angiogenesis, cell growth and proliferation (Lawrence, 2009). Additionally, it has been shown that $\mathrm{NF}-x \mathrm{~B}$ is constitutively activated in CRC and correlates with tumor progression (Kojima et al., 2004). Therefore, over-expression of COX-2, which can enhance malignant potential in CRC, may result from $\mathrm{NF}-x \mathrm{~B}$ activation.

In our previous study, a Japanese quince fruit flavanol preparation (JQFFP) demonstrated preventive and anticancer effects on several cell lines. JQFFP, particularly its fractions enriched in higher oligomers of procyanidins, inhibited activities of the type IV collagenases (MMP-2, 
MMP-9) secreted to the culture medium by human leukemia HL-60 cells and induced apoptosis in colon cancer Caco-2 cells (Stręk et al., 2007; Gorlach et al., 2011). Other studies had found that JQFFP induces apoptosis, suppresses invasiveness and down-regulates many genes crucial for development and progression of breast and prostate cancer cells (Lewandowska et al., 2013a), and that an ethanolic extract of Chaenomeles speciosa Nakai induces apoptosis in a murine $\mathrm{H}_{22}$ cell line and inhibits tumor growth in the Kunming mice (Yao et al., 2013). A recent study by Strugała et al. had found that Chaenomeles speciosa Nakai (Japanese quince, JQ) extract inhibits activity of the cyclooxygenase enzymes (COX-1 and COX-2) in a cell-free in vitro assay (Strugała et al., 2016).

Following up on these findings, together with the fact that COX-2 is one of the pro-inflammatory mediators whose expression may be induced at the very early steps of colorectal carcinogenesis, the study presented here examines influence of JQFFP on the COX-2 expression in the colon cancer SW-480 cells. It also assesses the influence of the tested preparation on MMP-9 and NF- $x \mathrm{~B}$ activation in those cells.

\section{MATERIALS AND METHODS}

Chemicals. Acetonitrile, (+)-catechin, (-)-epicatechin, and vanillin were purchased from Sigma-Aldrich Chemical Co. (St. Louis, MO, USA). Quercetin glucoside and quercetin galactoside were obtained from Extrasynthese (Lyon, France). Chlorogenic acid and procyanidin B2 were purchased from PhytoLab $\mathrm{GmbH} \&$ Co.KG (Vestenbergsgreuth, Germany). All other chemicals were reagent grade products purchased from POCH S.A. (Gliwice, Poland). Cell culture media and media supplements were purchased from Sigma-Aldrich (St. Louis, MO, USA).

Plant materials. Ripe fruit of Japanese quince (Chaenomeles japonica L., Rosaceae) was collected from bushes planted in a yard in the central region of Poland (The Research Institute of Horticulture in Skierniewice) and stored at $-20^{\circ} \mathrm{C}$ before polyphenol extraction.

Preparation of flavanol-rich extract from Japanese quince. Japanese quince dry flavanol extract was obtained according to Oszmiański (Oszmiański, 1992). In short, fresh pulp obtained from the Japanese quince fruit $(0.8$ $\mathrm{kg}$ ) was extracted twice with $90 \%$ acetone $(1: 2.5 \mathrm{w} / \mathrm{v})$, and then the pooled extracts were treated twice with trichloromethane $(1: 1 \mathrm{v} / \mathrm{v})$ to remove the lipids. Phenolics, mainly procyanidins (flavanols), were extracted from the water phase with ethyl acetate, and the obtained solutions were concentrated under vacuum (Rotavapor RII, $\mathrm{BUCHI})$. The final extract was precipitated from trichloromethane. The resulting preparation is subsequently referred to as Japanese quince fruit flavanol preparation (JQFFP) in this work. The dry JQFFP (3.9 g) was stored at $-20^{\circ} \mathrm{C}$ prior to further analyses. The JQFFP was characterized in terms of total polyphenol content, expressed as (+)-catechin equivalents, total flavanol content, expressed as $(+)$-catechin equivalents, as well as total proanthocyanidin content, expressed as cyanidin.

Total phenolic content. The total phenolic content of the JQFFP was determined by using the Folin-Ciocalteu reagent. Accurately weighed $20 \mathrm{mg}$ of extract was dissolved in $10 \mathrm{~mL}$ of $10 \%$ aqueous dimethyl sulfoxide; then, $0.1-0.2 \mathrm{~mL}$ were mixed with $25 \mathrm{~mL}$ of water, 0.5 $\mathrm{mL}$ of Folin-Ciocalteu reagent and $5 \mathrm{ml}$ of $20 \%$ sodium carbonate and made up to $50 \mathrm{~mL}$ with distilled water. The mixture was kept for $20 \mathrm{~min}$ at room temperature, after which the absorbance was read at $760 \mathrm{~nm}$. (+)-Catechin was used as a reference standard, and the results were expresses as milligram $(+)$-catechin equivalents in $1 \mathrm{~g}$ of dry mass of extract.

Total flavanol content. The vanillin assay was performed as described previously (Lewandowska et al., $2013 \mathrm{~b}$ ). In short, a volume of $2 \mathrm{~mL}$ of a known dilution of the preparation solution was placed in two test tubes, and $4 \mathrm{ml}$ of $1 \%(\mathrm{w} / \mathrm{v})$ vanillin in $70 \%$ sulfuric acid (A) or $4 \mathrm{~mL}$ of $70 \%$ sulfuric acid (B) were added to the sample. Additionally, a blank was prepared by mixing $2 \mathrm{~mL}$ of water with vanillin solution (C). All test tubes were shaken in a bath of cold water to prevent the temperature from rising above $35^{\circ} \mathrm{C}$. After incubation in cold water for $15 \mathrm{~min}$, the absorbance of samples A, B and $C$ was read at $500 \mathrm{~nm}$ against a mixture of $2 \mathrm{ml}$ of water and $70 \%$ sulfuric acid. The final absorbance is equal to the difference (A-B-C). The flavanols' content was calculated from a calibration curve, using (+)-catechin as a standard. Results were expressed as milligram $(+)$-catechin equivalents in $1 \mathrm{~g}$ of dry mass of extract.

Total proanthocyanidin content. The proanthocyanidins were determined after acid depolymerization to the corresponding anthocyanidins as described by Rösch (Rösch et al., 2003). 0.5-1.0 mg samples of dry flavanol extract were mixed with $10 \mathrm{~mL}$ of a solution of concentrated hydrochloric acid in $n$ butanol $(1: 9, \mathrm{v} / \mathrm{v})$ and heated for $90 \mathrm{~min}$ in a boiling water bath. After cooling on ice, the absorbance of samples was measured at $550 \mathrm{~nm}$. The content of proanthocyanidins was calculated with the molar extinction coefficient of cyanidin $(\varepsilon=17360 \mathrm{~L} /$ $\mathrm{mol} \times \mathrm{cm}$ and molar mass $287 \mathrm{~g} / \mathrm{mol}$ ) and was expressed as milligram cyanidin equivalents in $1 \mathrm{~g}$ of dry mass of extract.

Phenolics' identification by UPLC-Q-TOF-MS. Identification of polyphenol compounds was performed as described previously (Sałaga et al., 2014) using the Acquity Ultra-performance Liquid Chromatography (UPLC) system coupled with a quadrupole-time of flight (Q-TOF) MS instrument (UPLC/Synapt Q-TOF MS, Waters Corp., Miliford, MA, USA) with an electrospray ionization (ESI) source. Separation was achieved on an AcquityTM BEH C18 column $(100 \mathrm{~mm} \times 2.1 \mathrm{~mm}$ i.d., $1.7 \mu \mathrm{m}$; Waters). The mobile phase was a mixture of $4.5 \%$ formic acid (A) and acetonitrile (B). The gradient program was as follows: initial conditions $99 \%$ (A); $12 \mathrm{~min}, 75 \%$ (A); $12.5 \mathrm{~min}, 100 \%$ (B); $13.5 \mathrm{~min}$, $99 \%$ (A). The flow rate was $0.45 \mathrm{~mL} / \mathrm{min}$. The major operating parameters for the Q-TOF MS were set as follows: capillary voltage, $2.0 \mathrm{kV}$; cone voltage, $45 \mathrm{~V}$; cone gas flow, $11 \mathrm{~L} / \mathrm{h}$; collision energy, $50 \mathrm{eV}$; source temperature, $100^{\circ} \mathrm{C}$; desolvation temperature, $250^{\circ} \mathrm{C}$; collision gas, argon; desolvation gas, nitrogen; flow rate, $600 \mathrm{~L} / \mathrm{h}$; data acquisition range, $m /$ z. 100-1000 Da; ionization mode, negative. The data were collected by Mass-LynxTM V4.1 software.

HPLC analysis of phenolic compounds. HPLC analysis was performed by using an analytical reversedphase HPLC system (Dionex, Sunnyvale, CA, USA) with an EWPS-3000SI autosampler and LPG-3400A pump coupled to a photodiode array detector (Ultimate 3000), controlled by Chromeleon v. 6.8 software, according to Kucharska (Kucharska, 2012). Separation was performed on an Atlantis T3 $(250 \mathrm{~mm} \times 4.6 \mathrm{~mm}$ i.d., $5 \mu \mathrm{m}$; Waters, Dublin, Ireland). The eluent was $4.5 \%$ formic acid (A) and acetonitrile (B). A gradient solvent system was used: 0-1 min, 5\% (B); 1-6 min, 10\% (B); 6-26 min, 20\% (B); and $26-33 \mathrm{~min}, 100 \%$ (B). The flow rate was $1 \mathrm{~mL} / \mathrm{min}$, and the injection volume was $20 \mu \mathrm{L}$. Detector was set 
at $280 \mathrm{~nm}$ for flavan-3-ol derivatives and hydrolyzable tannin derivatives, and $360 \mathrm{~nm}$ for flavonol derivatives. The amounts of flavan-3-ol derivatives were expressed as $(+)$-catechin equivalents, hydrolyzable tannin derivatives as gallic acid equivalents, and flavonols as quercetin glucoside equivalents in $1 \mathrm{~g}$ of dry mass of extract.

Cells and culture conditions. SW-480 human colon cancer cells and CCD-18Co human colon fibroblast cells were purchased from the American Type Culture Collection (ATCC; ref: CCL-228 and CFR-1459) (LGC Standards, Poland). SW-480 cells were cultured in the Leibovitz's L-15 medium supplemented with 10\% fetal bovine serum (FBS), $2 \mathrm{mM}$ L-glutamine, $50 \mathrm{U} / \mathrm{mL}$ penicillin, $50 \mu \mathrm{g} / \mathrm{mL}$ streptomycin, and 1\% MEM nonessential amino acids. The cells were grown in a humidified atmosphere at $37^{\circ} \mathrm{C}$ without $\mathrm{CO}_{2}$. CCD-18Co cells were cultured in the Eagle's minimum essential medium supplemented with 10\% FBS, $2 \mathrm{mM}$ L-glutamine, $50 \mathrm{U} /$ $\mathrm{mL}$ penicillin, $50 \mu \mathrm{g} / \mathrm{mL}$ streptomycin, and 1\% MEM non-essential amino acids. Cells were grown in a humidified atmosphere with $5 \% \mathrm{CO}_{2}$ at $37^{\circ} \mathrm{C}$. All experiments were carried out between passages 4 and 17 . The cells were seeded in such a quantity that the confluence at the end of the experiment did not exceed $80 \%$ in the control wells. In the work presented here, JQFFP was tested within the concentration range of 25 to $150 \mu \mathrm{M}$ catechin equivalents (CE), which corresponds to 7.3-43.5 $\mu \mathrm{g} \mathrm{CE} /$ $\mathrm{mL}$ or $15.6-93.5 \mu \mathrm{g}$ of preparation $/ \mathrm{mL}$. For all bioassays, JQFFP was dissolved in a $70 \%$ ethanol solution in deionized water and then diluted to the final concentration with a serum-free medium. The final concentration of ethanol was lower than $0.01 \%(\mathrm{v} / \mathrm{v})$. Controls for the JQFFP treatment were incubated with ethanol. The experimental protocol was approved by the Ethics Committee of the Medical University of Lodz (No. $\mathrm{RNN} / 88 / 15 / \mathrm{KE})$.

Cell viability assay. Cell viability was assessed after 48 and 72 hour incubation with or without JQFFP (0-150 $\mu \mathrm{M}$ CE) by crystal violet staining, as described elsewhere (Lewandowska et al., 2013a). Briefly, the cells were harvested, suspended in the growth medium mentioned above, and seeded on 96-well plates (SW-480 and CCD-18Co were seeded at the densities of $10 \times 10^{3}$ and $6.0 \times 10^{3}$ per well, respectively). After $24 \mathrm{~h}$, the cells were washed twice with PBS and then suspended in a medium with $3 \%$ FBS. Next, the cells were treated with JQFFP for 48 and $72 \mathrm{~h}$. After culture, the medium was removed and the cells were fixed in situ with a $4 \%$ formaldehyde solution in PBS for $30 \mathrm{~min}$ at room temperature. Then, the cells were washed twice with PBS $(\mathrm{pH}$ 7.4) and stained for $5 \mathrm{~min}$ at room temperature with $0.5 \%$ crystal violet dissolved in $25 \%$ aqueous solution of methanol. Unbound dye was washed out with deionized water and the cells were allowed to air dry. The dye was solubilized in 33\% aqueous solution of acetic acid, while shaking for $30 \mathrm{~min}$ at room temperature by using a titer plate shaker (Lab-Line Instruments, Inc., Melrose Park, Illinois, USA). Optical density (OD) was measured by a microplate reader (iMarkTM, BioRad Laboratories) at a wavelength of $595 \mathrm{~nm}$. Each experimental condition was replicated three times, and the percentage of cell viability was calculated against untreated cells.

RNA isolation, cDNA synthesis and quantitative real time PCR. RNA isolation, cDNA synthesis and quantitative polymerase chain reaction (Q-PCR), experiments were performed according to the method of Lewandowska and coworkers (2013a). Briefly, cells were incubated in serum-free media, with or without JQFFP $(0-150 \mu \mathrm{M}$ CE), for $16 \mathrm{~h}$. Total RNA was isolated us- ing TRIzol ${ }^{\circledR}$ reagent (InvitrogenTM, Carlsbad, CA) following the manufacturer's guidelines. The concentration and purity of isolated RNA were determined spectrophotometrically at 260 and $280 \mathrm{~nm}$ (Colibri microvolume spectrometer, Titertek Berthold, Germany). cDNA synthesis was performed with $10 \mu \mathrm{g}$ of total RNA in a total volume of $40 \mu \mathrm{l}$, with a Maxima First Strand cDNA Synthesis Kit for RT-qPCR (Thermo Fisher Scientific, Rockford, USA). Next, cDNA samples were diluted with RNase-free water to a total volume of $160 \mu \mathrm{L}$. Volumes of $2 \mu \mathrm{l}$ (corresponding to $0.125 \mu \mathrm{g}$ of total RNA) were used for Q-PCR which was carried out using the RotorGene TM 3000 (Corbett Research) thermocycler. Detection of Q-PCR products was done in a total volume of $20 \mu \mathrm{l}$ using Rotor-Gene SYBER Green PCR Kit (Qiagen Inc., Crawley, UK). Prostaglandin-endoperoxide synthase 2 (prostaglandin $\mathrm{G} / \mathrm{H}$ synthase and cyclooxygenase) (PTGS2) (Hs_PTGS2_1_SG detecting transcript of NM 000963 ) primers were from Qiagen. The Q-PCR amplification procedure was comprised of the following stages: initial denaturation step at $95^{\circ} \mathrm{C}$ for $5 \mathrm{~min}$, followed by 40 cycles of $95^{\circ} \mathrm{C}$ for $10 \mathrm{~s}$ (melting) and $60^{\circ} \mathrm{C}$ for $10 \mathrm{~s}$ (annealing and extension). Gene expression levels were normalized using two reference genes: beta-2-microglobulin (B2M) (Hs_B2M_1_SG detecting transcripts of NM 004048/XM 005254549/XM 006725182) and glyceraldehyde-3-phosphate dehydrogenase (GAPDH) (Hs_GAPDH_1_SG detecting transcripts of NM 001256799/NM 002046/NM 001289745/NM 001289746) (Qiagen Inc., Valencia, CA). Relative expression was calculated according to the Roche's method using the Universal Human Reference RNA (Stratagene, La Jolla, CA) as a reference (Pfaffl et al., 2002).

Protein preparation and Western blot analysis. Cells were harvested, suspended in growth medium, and seeded in $75 \mathrm{~cm}^{2}$ bottles. After $24 \mathrm{~h}$, the cells were washed twice with PBS and then suspended in a serumfree medium. Subsequently, the cells were treated with JQFFP within the concentration range of $25-100 \mu \mathrm{M}$ $\mathrm{CE}$ and incubated for $48 \mathrm{~h}$. Control samples were incubated without JQFFP. Cell lysates were prepared using a Mammalian Cell Lysis Kit (Sigma-Aldrich Co. LLC, St. Louis, MO, USA), supplemented with the proteaseinhibitor mix M (Serva Electrophoresis, Heidelberg, Germany). The protein content of the cell lysates was then determined by using the Bradford reagent (BioRad, Hercules, CA, USA). Equal amounts of protein cell lysates $(50 \mathrm{mg}$ ) were subjected to SDS-PAGE in $12-15 \%$ polyacrylamide gel and transferred onto a $0.22-$ $0.45 \mathrm{~mm}$ nitrocellulose membrane (BioRad, Hercules, CA, USA). The membranes were blocked with $3 \%(\mathrm{w} / \mathrm{v})$ non-fat milk in Tris-Buffered Saline with Tween (TBST) and incubated with primary antibodies at the following concentrations: goat anti-COX-2 (sc-1745, Santa Cruz Biotechnology, Santa Cruz, CA, USA), 1:100; rabbit antiNF- $x$ B p65 (sc-109, Santa Cruz Biotechnology), 1:200; mouse anti-MMP-9 (sc-21733, Santa Cruz Biotechnology), 1:200; rabbit anti-actin (A5060, Sigma-Aldrich Co. LLC, St. Louis, MO, USA), 1:1000. Afterwards, secondary antibodies (horseradish peroxidase-conjugated) were used at the following concentrations: donkey anti-goat IgG (sc-2020, Santa Cruz Biotechnology), 1:20000; antirabbit IgG (A0545, Sigma-Aldrich Co. LLC, St. Louis, MO, USA), 1:100000; and anti-mouse IgG (sc-2005, Santa Cruz Biotechnology), 1:5,000. The membranes were washed, and detection was performed using the enhanced chemiluminescence blotting detection system (SuperSignal West Pico Chemiluminescent Substrate, ThermoFisher Scientific, Rockford, USA). The intensity 
of the bands was quantified by densitometric analysis using the GelDoc ${ }^{\mathrm{TM}} \mathrm{EQ}$ system with Quantity One software (Bio-Rad Laboratories, Inc., Hercules, CA, USA). Immunoblots were normalized to the $\beta$-actin content.

Enzyme-linked immuno-sorbent assay (ELISA). Cells were suspended in the growth medium mentioned above and seeded in bottles $\left(4 \times 10^{5} / 25 \mathrm{~cm}^{2}\right.$ bottle) and incubated for $24 \mathrm{~h}$ to allow attachment. The attached cells were washed twice with PBS and suspended in $5 \mathrm{~mL}$ of a serum-free medium, with or without JQFFP (0-100 $\mu \mathrm{M} \mathrm{CE})$, for $48 \mathrm{~h}$. After $48 \mathrm{~h}$, the medium was removed and the cells were washed with PBS, followed by incubation in the CytoBuster Protein Extraction Reagent (Novagen, Hercules, CA, USA) at room temperature for $5 \mathrm{~min}$. Next, the lysates were cleared by centrifugation at $16000 \times g$ for $5 \mathrm{~min}$ at $4^{\circ} \mathrm{C}$, and the supernatants (cell extracts) were stored at $-70^{\circ} \mathrm{C}$ for further analysis. The protein content of the cell lysates was then determined using Bradford reagent (BioRad, Hercules, CA, USA). Enzyme linked immunosorbent assay (CBA053, Calbiochem ${ }^{\circledR}$ COX-2 ELISA Kit, Merck Millipore) was used for quantitative determination of the COX-2 levels in cell lysates according to the manufacturer's protocol. In short, standard, control, and lysate samples were added to 96-well plates coated with a rabbit anti-human COX-2 polyclonal antibody (capture antibody). COX-2 was then detected with a monoclonal anti-COX-2 antibody and a goat anti-mouse IgG HRP-conjugate. Subsequently, a tetramethyl-benzidine substrate was added to each well, giving a blue-colored product in the presence of the HRP-conjugate. Finally, the absorbance was measured at the wavelengths of $450 \mathrm{~nm}$ by a microplate reader and the COX-2 content was calculated according to a standard curve.

Gelatin zymography assay and quantitative analysis of MMP-2 and MMP-9 secretion. SW-480 cells were harvested, suspended in the growth medium mentioned above and seeded at the density of $8 \times 10^{3}$ per well on 96-well plates. After $24 \mathrm{~h}$, the cells were washed twice with PBS and then suspended in a serum-free medium with various concentrations of JQFFP, or without it, for $48 \mathrm{~h}$. Gelatin zymography of the cell culture media samples was performed following the method of Lewandowska and coworkers (2014). In short, the same volumes of the media $(20 \mu \mathrm{l})$ were dissolved in an electrophoresis sample buffer containing sodium dodecyl sulfate and subjected to electrophoresis in a $10 \%$ polyacrylamide gel embedded with gelatin $(1 \mathrm{mg} / \mathrm{mL})$ in the absence of $\beta$-mercaptoethanol. After electrophoresis, type IV collagenases (MMP-2 and MMP-9) were renatured by incubation with $2 \%$ Triton $\mathrm{X}-100$, and the enzymatic reaction was allowed to proceed at $37^{\circ} \mathrm{C}$ for $21 \mathrm{~h}$. Thereafter, the gels were stained for $1.5 \mathrm{~h}$ with $0.0125 \%$ Amido Black in $7 \%$ acetic acid and $20 \%$ ethanol. Type IV collagenases were visualized without destaining as transparent bands against the dark blue background of Amido Blackstained slab gels. Densitometry analysis was carried out using GelDoc TMEQ system with Quantity One software (Bio-Rad Laboratories, Inc., Hercules, CA, USA).

Phosphorylation detection by flow cytometry. SW480 cells were seeded at a density of $1.2 \times 10^{5}$ per $60 \mathrm{~mm}$ well in $5 \mathrm{~mL}$ of a culture medium (L-15) containing $10 \%$ FBS. After $24 \mathrm{~h}$ of initial incubation, the cells were washed twice with PBS and suspended in $5 \mathrm{~mL}$ of a serum-free L-15 and with $100 \mu \mathrm{M}$ CE JQFFP. Control samples were incubated without JQFFP. The incubation lasted for $48 \mathrm{~h}$. Next, the cells were fixed with the BD Cytofix Fixation Buffer (BD Biosciences), permeabilized at a concentration of $1 \times 10^{6} / \mathrm{mL}$ with the Perm Buffer
III, and stained according to the manufacturer of the PE-CF594 Mouse Anti-Human NF- $x$ B p65 (pS529) (BD Biosciences, Bedford, MA, USA). The stained samples were immediately analyzed with the use of a flow cytometer (Canto II, BD Biosciences). Data was processed using FACSDiva 6.1.3 software (Becton Dickinson). Four independent experiments were carried out.

Statistical analysis. Statistical analyses were performed using PRISM 5.0 (GraphPad Software Inc., La Jolla, CA, USA). Data is presented as mean \pm S.D. or SEM, as indicated in the figure legends. The number of independent experiments is given in the figure legends. The statistical significance of differences between means was determined by a one-way ANOVA followed by a post hoc multiple comparison Newman-Keuls test. $P$ values of $<0.05$ were considered to be statistically significant.

\section{RESULTS}

\section{Characterization of JQFFP composition}

The composition of JQFFP was determined by both, spectrophotometric and UPLC-Q-TOF-MS chromatographic methods (Table 1 and Table 2). A representative chromatogram for the analysis of JQFFP components is depicted in Fig. 1. Japanese quince fruit was revealed to be a rich source of highly diversified polyphenols: colorimetric analysis had found its total polyphenol content to be $465.31 \pm 32.22 \mathrm{mg} / \mathrm{g}$, and flavanols constituted $47.16 \%$ $(219.46 \pm 11.67 \mathrm{mg} / \mathrm{g})$ of the preparation. The UPLC-QTOF-MS analysis showed that the predominant compounds in JQFFP were flavan-3-ol derivatives such as procyanidin monomers and oligomers, ranging from dimers to pentamers, which accounted for about $92.58 \%$, with chlorogenic acid constituting 6.34\%.

\section{Effect of JQFFP on viability of SW-480 and CCD-18Co cells}

As demonstrated in Fig. 2, the influence of JQFFP on viability of SW-480 colon cancer cells (Fig. 2A) and CCD-18Co colon fibroblast cells (Fig. 2B) was also assessed. The cells were treated with various concentrations of JQFFP ranging from $25 \mu \mathrm{M}$ CE to $150 \mu \mathrm{M}$ CE. JQFFP reduced SW-480 cell viability after 48 and $72 \mathrm{~h}$ of incubation. After the $72 \mathrm{~h}$ incubation with JQFFP, the number of live SW-480 cells decreased in a concentration-dependent manner: falling by $20 \%$ with regard to control (untreated cells) at $75 \mu \mathrm{M} \mathrm{CE}, 25 \%$ at $100 \mu \mathrm{M}$ $\mathrm{CE}, 28 \%$ at $125 \mu \mathrm{M} \mathrm{CE}$ and $40 \%$ at $150 \mu \mathrm{M}$ CE. In addition, statistically significant viability inhibition was observed. After the shorter incubation time $(48 \mathrm{~h})$ with JQFFP, significant inhibition of cell viability was detected in the concentration range of $125-150 \mu \mathrm{M} \mathrm{CE}(15 \%$ and $30 \%$, respectively). It is worth noting that JQFFP did not influence the CCD-18Co cell viability after either

Table 1. General characteristic of JQFFP ( $\mathrm{mg} / \mathrm{g}$ dry preparation; mean \pm S.D., $n \geq 3$ )

\begin{tabular}{lc}
\hline Spectrophotometric analysis & \\
\hline Total polyphenols $\mathrm{s}^{\mathrm{a}}$ & $465.31 \pm 32.22$ \\
\hline Total flavanols & \\
\hline Total proanthocyanidinsc & $219.46 \pm 11.67$ \\
\hline
\end{tabular}

aDetermined by Folin-Ciocalteu reagent as $(+)$-catechin equivalents. bDetermined by vanillin reagent as (+)-catechin equivalents. 'Determined by acid hydrolysis as cyanidin equivalents. 
Table 2. UPLC-ESI/MS data for polyphenols identified in JQFFP (mg/g dry preparation)

\begin{tabular}{|c|c|c|c|c|c|c|}
\hline $\begin{array}{l}\text { Peak } \\
\text { number }\end{array}$ & $\begin{array}{l}\mathrm{R}_{\mathrm{t}} \\
(\mathrm{min})\end{array}$ & $\begin{array}{l}{[\mathrm{MS}-\mathrm{H}]^{-}} \\
(\mathrm{m} / \mathrm{z})\end{array}$ & MS/MS $(m / z)$ & Compound & $\begin{array}{l}\text { Chemical } \\
\text { entity }\end{array}$ & $\begin{array}{l}\text { Quantity } \\
\text { (mg/g) }\end{array}$ \\
\hline 1 & 2.61 & 577,1349 & $407,0768 / 289,0688 / 125,0241$ & procyanidin dimer & flavan-3-ols & \multirow{2}{*}{21.07} \\
\hline 2 & 2.72 & 577,1349 & $407,0768 / 289,0688 / 125,0242$ & procyanidin dimer & flavan-3-ols & \\
\hline 3 & 2.91 & 865,1905 & $577,1349 / 407,0768 / 289,0727 / 125,0218$ & procyanidin trimer & flavan-3-ols & 0.45 \\
\hline 4 & 3.07 & 865,1906 & $577,1349 / 407,0768 / 289,0768 / 125,0264$ & procyanidin trimer & flavan-3-ols & 0.23 \\
\hline 5 & 3.22 & 289,0723 & $151,0394 / 125,0264$ & $(+)$-catechin & flavan-3-ols & 0.40 \\
\hline 6 & 3.62 & 353,0879 & 191,0553 & chlorogenic acid & phenolic acid & 17.68 \\
\hline 7 & 3.81 & 1153,2637 & $573,1207 / 287,0610$ & procyanidin tetramer & flavan-3-ols & 3.08 \\
\hline 8 & 3.98 & 577,1349 & $407,0810 / 289,0723 / 125,0241$ & procyanidin B2 & flavan-3-ols & 72.08 \\
\hline 9 & 4.77 & 289,0723 & $151,0394 / 125,0264$ & (-)-epicatechin & flavan-3-ols & 43.30 \\
\hline 10 & 5.12 & 865,1967 & $577,1349 / 287,0540 / 125,0241$ & procyanidin trimer & flavan-3-ols & 43.78 \\
\hline 11 & 5.36 & 1153,2568 & $865,1906 / 577,1349 / 289,0688$ & procyanidin tetramer & flavan-3-ols & 33.63 \\
\hline 12 & 5.42 & 1441,3274 & $1153,2706 / 863,1810 / 575,1109 / 289,0688$ & procyanidin pentamer & flavan-3-ols & 24.77 \\
\hline 13 & 5.53 & 431,1887 & 287,0540 & procyanidin & flavan-3-ols & 11.10 \\
\hline 14 & 7.18 & 463,0887 & $301,0319 / 271,0245$ & quercetin 3-O-galactoside & flavonols & 1.27 \\
\hline 15 & 7.29 & 577,1349 & $407,0727 / 289,0688 / 125,0241$ & procyanidin dimer & flavan-3-ols & \multirow{2}{*}{4.01} \\
\hline 16 & 7.37 & 865,1967 & $577,1398 / 407,0768 / 289,0768 / 125,0264$ & procyanidin trimer & flavan-3-ols & \\
\hline 17 & 7.44 & 463,0887 & $301,0319 / 271,0245$ & quercetin $3-O$-glucoside & flavonols & 1.71 \\
\hline
\end{tabular}

Flavan-3-ol derivatives were determined by HPLC at $280 \mathrm{~nm}$ as (-)-epicatechin

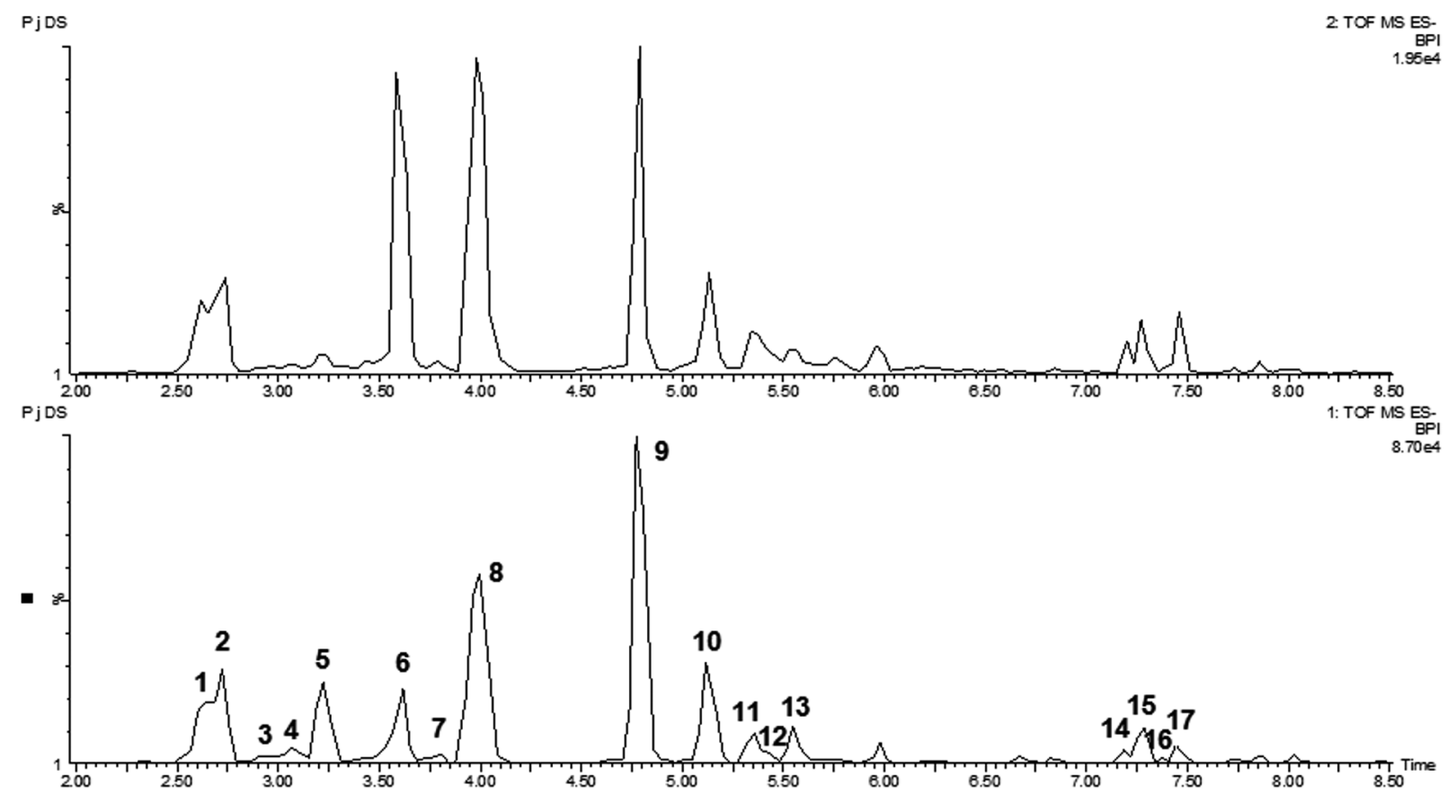

Figure 1. Base peak chromatogram of the JQFFP obtained by an MS data collection technique (UPLC-Q-TOF/MS ES) in a negative ionization mode.

The lower chromatogram presents the sample before fragmentation, and the upper chromatogram after fragmentation. Peaks are labeled according to Table 2 . 


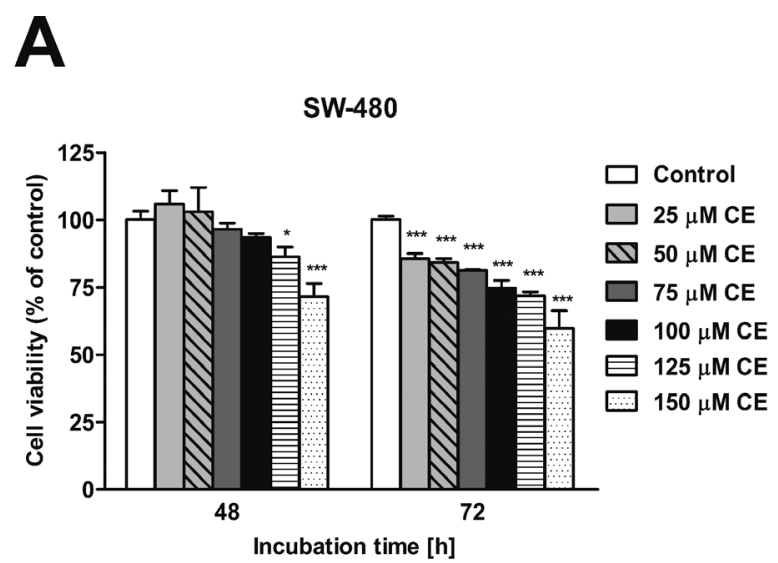

B

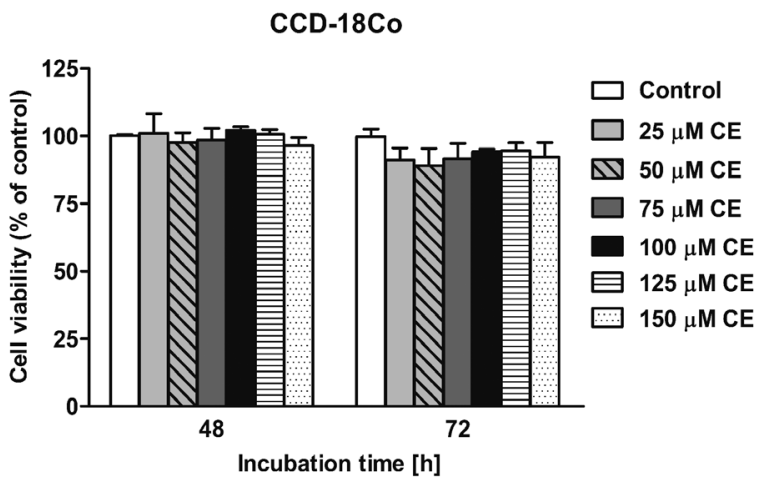

Figure 2. The influence of JQFFP on the SW-480 (A) and CCD$18 \mathrm{Co}$ (B) cell viability, determined on the basis of crystal violet staining.

The results are expressed as the percentage of control values (untreated cells). Each value represents the mean value \pm S.D., $n=3$ independent experiments (each experiment was carried out in triplicate). Significance of differences between means: ${ }^{*} p<0.05$, ${ }^{* *} p<0.01,{ }^{* * *} p<0.001$ versus control.

48 or $72 \mathrm{~h}$ incubation throughout the whole concentration range chosen for the study (Fig. 2B). The obtained results indicate that the tested JQFFP has an inhibitory effect on colon cancer cell viability.

\section{JQFFP inhibits both, COX-2 mRNA and protein expression, in SW-480 cells}

mRNA expression was measured by Q-PCR. As presented in Fig. 3A, the expression of COX-2 mRNA was significantly reduced in a concentrationdependent manner following $16 \mathrm{~h}$ incubation with JQFFP. At concentrations of 25, 50, and $100 \mu \mathrm{M} \mathrm{CE}$, the COX-2 expression was reduced to $66.9 \%, 76.2 \%$, and $36.7 \%$, respectively, when compared to control. Subsequently, it was determined whether the differences in COX-2 protein expression resulted from an altered COX-2 mRNA expression in SW-480. Western blot analysis confirmed the ability of JQFFP to inhibit COX-2 expression not only at the level of mRNA, but also at the protein level, as shown in Fig. 3B. The observed effect was dependent on the concentration of JQFFP, reaching $91 \%, 86 \%$, and $77 \%$ for 25,50 , and $100 \mu \mathrm{M} \mathrm{CE}$, respectively, after $48 \mathrm{~h}$ of incubation. Also, a similar tendency was observed in another
A

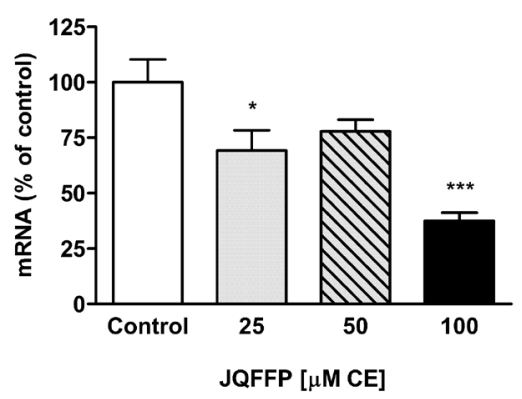

B
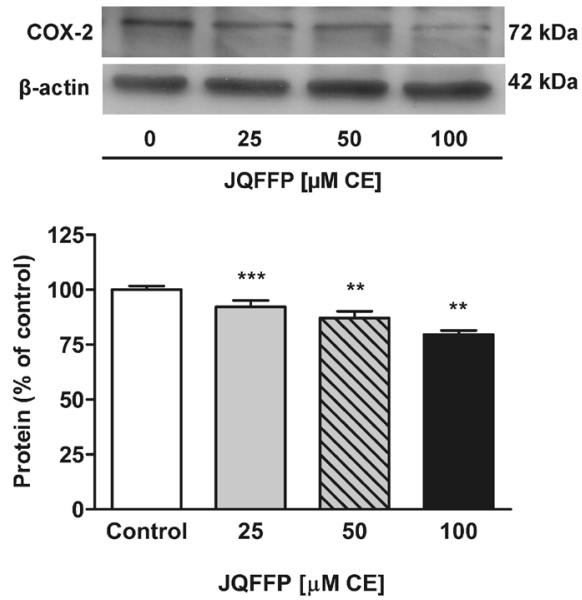

C

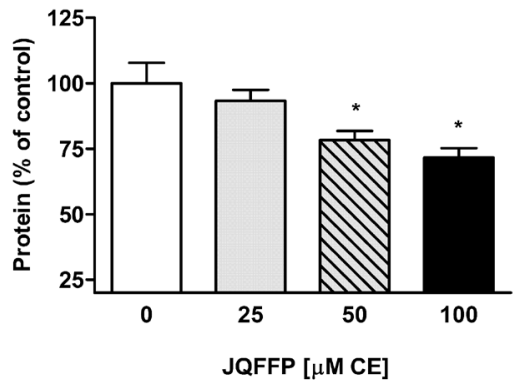

Figure 3. Quantitative polymerase chain reaction (Q-PCR) analysis of COX-2 mRNA in SW-480 (A) cells incubated for 16 hours with JQFFP at concentrations of 25,50, and $100 \mu \mathrm{M}$ CE. The effect of JQFFP on expression of the COX-2 protein in SW-480 cells (B and C).

Protein expression of COX-2 in SW-480 cells incubated with different concentrations of JQFFP $(25,50$, and $100 \mu \mathrm{M}$ CE) for 48 hours was examined by Western blot assay (B) and an enzyme-linked immunosorbent assay (C). Control expression level obtained for untreated cells was taken as $100 \%$. Each value on the graphs represents the mean value \pm S.E.M., $n=3$ independent experiments. Significance of differences between means: ${ }^{*} p<0.05,{ }^{* *} p<0.01$, ${ }_{* * *} p<0.001$ versus control.

study of quantitative determination of COX-2 protein in cell lysates by ELISA. As shown in Fig. 3C, JQFFP down-regulated the expression of $\mathrm{COX}-2$ protein in SW-480 cells. At JQFFP concentrations of 25, 50, and $100 \mu \mathrm{M} \mathrm{CE}$, the expression level of pro-inflammatory COX -2 protein decreased to $93 \%, 78 \%$, and $72 \%$, respectively, versus untreated control. The above-mentioned results indicated that JQFFP can reduce the COX-2 levels (mRNA and protein) in the SW-480 cell 

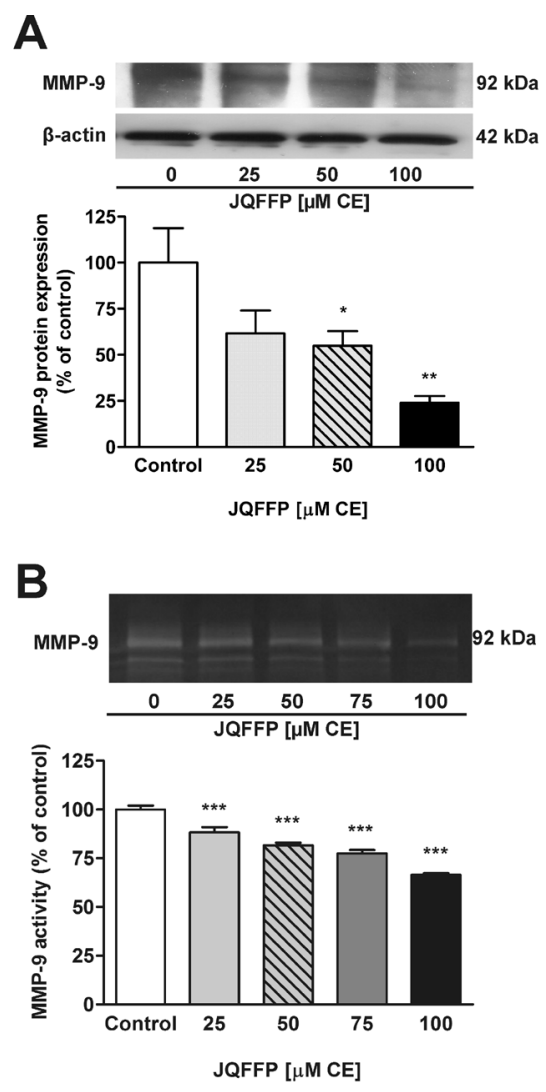

\section{C}

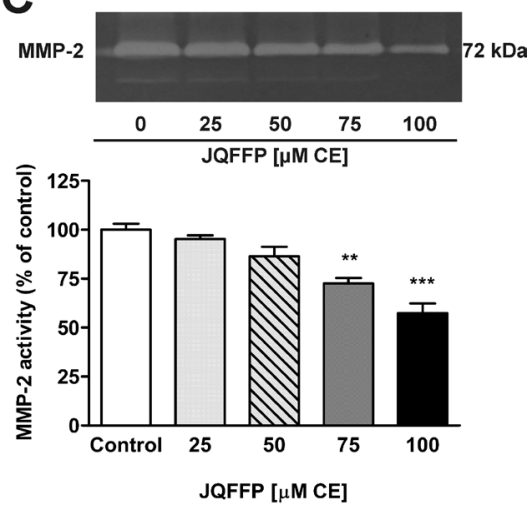

Figure 4. The effect of JQFFP on the expression level of MMP-9 protein in SW-480 cells.

Western blot and densitometric analysis of the resulting immunoblots (A). The cells were treated with JQFFP $(25,50$, and 100 $\mu \mathrm{M}$ CE) for $48 \mathrm{~h}$. Quantification of protein bands was performed after densitometric analysis scanning of immunoblots and normalized to the $\beta$-actin level. The normalized amount of protein in control (untreated cells) was taken as $100 \%$. Inhibition of type IV collagenases (MMP-9 and MMP-2) secreted to culture medium of SW-480 cell line (B and C). Zymographic analysis of the media was carried out after $48 \mathrm{~h}$ incubation with JQFFP $(25,50,75$, and $100 \mu \mathrm{M}$ (E). Representative zymograms are shown above the graphs. Each value on the graphs represents the mean value \pm S.E.M., $n=3$ independent experiments. Significance of differences between means: ${ }^{*} p<0.05,{ }^{* *} p<0.01,{ }^{* * *} p<0.001$ versus control.

line and in a consequence exerts an anti-inflammatory effect in those cells.

\section{JQFFP inhibits MMP-9 protein expression}

JQFFP treatment caused a statistically significant and concentration-dependent reduction in protein expression of MMP-9, as determined by Western blotting methods
A
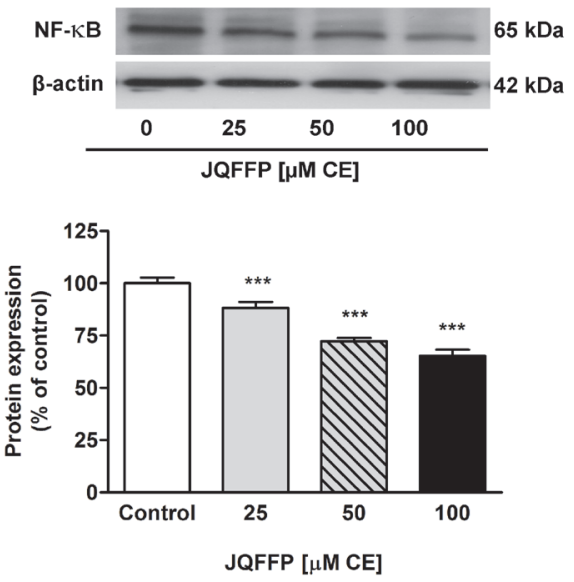

B

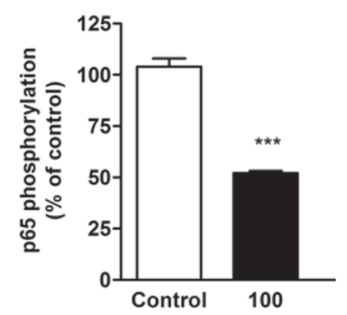

JQFFP $[\mu \mathrm{M} C E]$

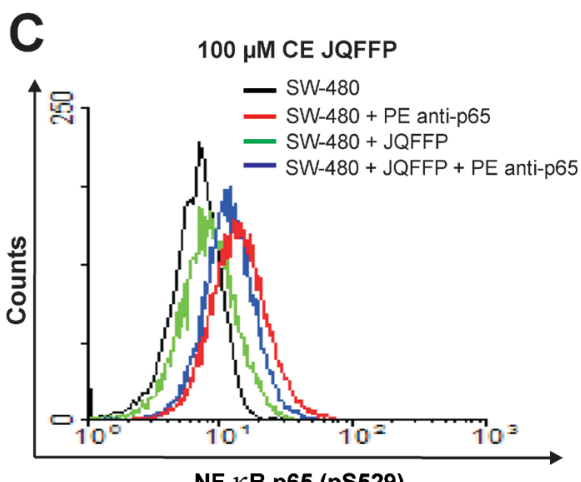

NF-KB p65 (pS529)

Figure 5. The effect of JQFFP on the expression of NF-KB protein in SW-480 cells $(A)$.

Protein expression of NF-KB in SW-480 cells incubated with different concentrations of JQFFP $(25,50$, and $100 \mu \mathrm{M}$ CE) for 48 hours, was examined by a Western blot assay. Quantification of protein bands was performed after densitometric analysis scanning of immunoblots and normalized to the $\beta$-actin level. The normalized amount of protein in control (untreated cells) was taken as $100 \%$. (B) The effect of JQFFP on the phosphorylation of NF-KB p65 in SW-480 cells. The cells were incubated without or with JOFFP $(100 \mu \mathrm{M} \mathrm{CE})$ for 48 hours and then stained with fluorescentlylabeled antibody (PE - mouse anti-human NF-KB p65). Values are expressed as a percentage of the untreated cells (control). Each value on the graph represents the mean value \pm S.E.M., $n=4$ independent experiments. Significance of differences between means: ${ }^{*} p<0.05,{ }^{* *} p<0.01,{ }^{* * *} p<0.001$ versus control. (C) Representative flow cytometry trace showing the effect of JQFFP on the phosphorylation of NF-kB p65. PE=phycoerythrin

(Fig. 4A); this reduction was not statistically significant only at the lowest concentration of JQFFP (25 $\mu \mathrm{M} \mathrm{CE})$. At JQFFP concentrations of 25, 50, and $100 \mu \mathrm{M} \mathrm{CE}$, the expression of MMP-9 protein decreased to $61 \%$, $54 \%$, and $24 \%$, respectively, vs. control. After $48 \mathrm{~h}$ of 
incubation with JQFFP, the activity of MMP-9 secreted to the culture medium by SW- 480 cells was considerably reduced and, as shown in Figure $4 \mathrm{~B}$, at the concentrations of $25,50,75$, and $100 \mu \mathrm{M}$ CE, the inhibition reached $12 \%, 19 \%, 23 \%$, and $35 \%$, respectively, which clearly demonstrates a concentration-dependent effect. Additionally, gelatin zymography had found the tested preparation to inhibit secretion of the MMP-2 (Fig. 4C). This inhibition of MMP-9 by JQFFP suggests that it acts as an antimetastatic and antiangiogenic agent.

\section{JQFFP inhibits both, the NF-KB protein expression and NF-KB p65 (Ser 529) phosphorylation, in SW-480 cells}

Due to the fact that activities of COX-2 and MMP-9 are highly dependent on the transcription factor $\mathrm{NF}-\varkappa \mathrm{B}$, the next stage of our research was set to assess the impact of JQFFP on the NF- $x \mathrm{~B}$ protein expression. Western blot studies revealed that JQFFP caused a statistically significant and concentration-dependent reduction in the expression of the $\mathrm{NF}-\varkappa \mathrm{B}$ transcription protein factor (Fig. 5A). At JQFFP concentrations of 25, 50, and $100 \mu \mathrm{M}$ CE, expression of the NF- $x \mathrm{~B}$ protein decreased to $88 \%, 71 \%$, and $65 \%$, respectively, versus control. As $\mathrm{NF}_{-\mathrm{K}} \mathrm{B}$ proteins, such as $\mathrm{p} 65$, require phosphorylation within their transactivation domain to optimally regulate expression of multiple target genes, including COX-2 and MMP-9, the next stage assessed impact of JQFFP on phosphorylation of the p65 subunit. The phosphorylation level of p65 was determined using a monoclonal antibody recognizing the phosphorylated serine 529 (pS529) in the transactivation domain of the NF-кB p65 subunit. Flow cytometry analysis revealed that at a JQFFP concentration of $100 \mu \mathrm{M}$ CE, the phosphorylation level of the p65 subunit was reduced by $49 \%$ in respect to control (Fig. 5B and 5C). Our findings indicate that JQFFP has the ability to decrease both, the expression of NF- $x$ B protein and the phosphorylation of the NF-KB p65 subunit, in the SW-480 cells.

\section{DISCUSSION}

A growing body of evidence suggests that dietary plant-derived compounds, including polyphenols, have anti-inflammatory and anticancer properties that can be mediated through COX-2 (Shanmugam et al., 2011). Additionally, evidence suggests existence of an association between CRC and COX-2 over-expression by creating a microenvironment conducive for the development of pre-neoplastic lesions (Temraz et al., 2013). Thus, selective inhibition of the COX-2 enzyme could hinder the development and progression of CRC. Research of celecoxib, a cyclooxygenase- 2 selective inhibitor, has demonstrated that it can effectively decrease the number of colorectal polyps (Steinbach et al., 2000). Likewise, in clinical trials carried out in 1561 patients, celecoxib significantly reduced the risk of colorectal adenomas within three years after polypectomy. Unfortunately, it was associated with serious adverse events related to a cardiovascular disease (Arber et al., 2006, ClinicalTrials.gov number, NCT00005094). Due to the fact that celecoxib and other non-steroidal anti-inflammatory drugs (NSAIDs) can cause severe side effects (e.g., gastrointestinal ulceration, bleeding, and platelet dysfunction), an increasing number of studies has focused on finding new, low or non- toxic anti-inflammatory drugs. Compounds from natural sources might be a promising alternative strategy to synthetic COX-2 inhibitors for inflammation prevention and therapy. Numerous studies in different cell lines and animal models suggest that polyphenols and polyphenol-rich extracts have a preventive, anti-inflammatory effect against CRC (Sałaga et al., 2014; Zielińska et al., 2015).

Our previous study had found that a JQFFP exhibits a potent antiproliferative effect against breast and prostate cancer cells, inhibits their invasiveness, and decreases expression of several genes involved in apoptosis, angiogenesis, and metastasis (Lewandowska et al., 2013a). The work presented here, investigates the potential of JQFFP as an anti-inflammatory agent in colon cancer cells. The initial step was to determine the impact of JQFFP, found to be rich in procyanidin monomers and oligomers ( $\mathrm{Ta}-$ ble 2) on the viability of human colon cancer cells (SW480) and normal human colon fibroblasts (CCD-18Co). The tested flavanol preparation had demonstrated opposite effects towards colon cancer cells (SW-480) and normal colon fibroblast cells (CCD-18Co) (Fig. 2A and 2B); JQFFP reduced colon cancer cell viability in a time- and concentration-dependent manner but was not toxic to normal cells. Such results indicate that JQFFP exhibits an antiproliferative effect against SW-480 cells and may act as a protective agent towards CCD-18Co fibroblast cells which are part of the gut barrier and constitute an important component in the maintenance of the intestinal mucosa (Ivanov et al., 2010). These observations are similar to our previous report demonstrating that the JQFFP suppresses the growth of both, highly metastatic breast and prostate cancer cells (MDA-MB-231 and DU 145) but did not decrease the normal PNT1A human prostate cell number (Lewandowska et al., 2013a). Our results are in accordance with other literature data regarding the sensitivity of various types of cells to growth inhibitors of plant origin (Carvalho et al., 2010). For instance, Dias and coworkers (2014) found that a polyphenol extract from acai (Euterpe oleracea Mart.) does not influence the CCD-18Co cell viability at all, but significantly reduces growth of the SW-480 cell line. Likewise, previous studies have found that normal and cancer cells originated from the gastrointestinal tract (Caco-2, HT-29, IEC-6) have variable sensitivities to the antiproliferative activity of flavanols obtained from the Japanese quince fruit (Gorlach et al., 2011). SW-480 was chosen for the study as it is known to be inhibited by JQFFP.

Our findings indicate that JQFFP down-regulated COX-2 mRNA expression in SW-480 at each concentration of the tested flavanol preparation $(63 \%$ vs. control at $100 \mu \mathrm{M}$ CE) (Fig. 3A). Furthermore, we have shown that inhibition of COX-2 mRNA expression by JQFFP correlated with lower levels of COX-2 protein in a concentration-dependent manner, as evidenced by both, Western blot and ELISA (Fig. 3B and 3C). This downregulation of COX-2 by JQFFP observed in the SW-480 cell line suggests that it possesses an anti-inflammatory activity. These findings are in agreement with those of a recent study which had shown that Japanese quince (JQ) extract has the capacity to inhibit the COX-1 and COX2 enzymes. It should be noted, however, that this inhibition of COX-1 and COX-2 by JQ was analyzed in a cell-free in vitro assay (Strugała et al., 2016). Besides this, the anti-inflammatory activity of JQFFP is consistent with the previously reported anti-inflammatory activity of a $10 \%$ ethanol fraction of Chaenomeles speciosa observed on carrageenan-induced rat paw edema ( $\mathrm{Li}$ et al., 2009).

Furthermore, it has been found that COX-2 expression may be associated with the invasive and metastatic properties of CRC tumor cells (Chen et al., 2001). In one such study, Tsujii and coworkers (1997) had demonstrated that COX-2-overexpression in the Caco- 
2 cells increases activity of MMPs and stimulates their ability to promote endothelial cell motility through a matrix, which could be abrogated by treatment with COX inhibitors. It is also well known that overexpression of MMPs, particularly MMP-9, may be one part of the multi-step process that leads to neoplastic cell proliferation and metastasis in CRC (Cho et al., 2007). As previous studies have shown that JQFFP had decreased the MMP-9 expression level and its activity in prostate cancer cells (DU 145) (Lewandowska et al., 2013a), the study presented here examined the influence of JQFFP on MMP-9 activity in the SW-480 cells. The flavanol preparation reduced MMP-9 protein expression in a concentration-dependent manner $(76 \%$ vs. control at $100 \mu \mathrm{M}$ CE) (Fig. 4A). In addition, JQFFP inhibited activity of the MMP-9 secreted into the culture medium by SW-480 cells. The observed inhibition was concentration-dependent and statistically significant (Fig. 4B). We also noted that the tested preparation inhibited activity of MMP-2 (Fig. 4C). The above-mentioned results indicate that the down-regulation of MMP-9 protein expression by JQFFP in the SW-480 cells could be related to the marked repression of the COX-2 gene transcription.

According to the literature data, both COX-2 and MMP-9 promoter regions are highly conserved and contain NF-xB binding sites (Takada et al., 2003). $\mathrm{NF}-x \mathrm{~B}$ exists in a latent state in the cytoplasm as p65(RelA)/p50 heterodimers bound to the inhibitory protein $\mathrm{I} \varkappa \mathrm{B}$, which prevents nuclear translocation of NF-xB (Tergaonkar et al., 2005). Phosphorylation of $\mathrm{NF}-x \mathrm{~B}$ in response to various inflammatory stimuli results in a proteasome-mediated $\mathrm{I} x \mathrm{~B}$ degradation and ctivation of the NF-xB (Tergaonkar et al., 2005; Viatour et al., 2005). Subsequently, NF- $x \mathrm{~B}$ translocates to the nucleus, where it binds to the NF- $x \mathrm{~B}$-binding sites in the promoter region of target genes, thereby promoting transcription of many genes, including COX2 and MMP-9 (Tazawa et al., 1994; Shin et al., 2007). It has been shown that optimal induction of NF- $x \mathrm{~B}$ target genes also requires phosphorylation of the NF- $x \mathrm{~B}$ proteins, such as $\mathrm{p} 65$, within their transactivation domains (Viatour et al., 2005). Wang and coworkers (2000) had shown that phosphorylation of serine 529 contributes to the ability of $\mathrm{p} 65$ to activate a $x \mathrm{~B}$ dependent reporter. As this transcriptional factor is constitutively activated in human colorectal carcinoma tissue and correlates with tumor progression (Kojima et al., 2004), the next stage of our study had examined whether the COX-2 and MMP-9 activity inhibition by JQFFP in the SW-480 cells is mediated through $\mathrm{NF}-x \mathrm{~B}$. We have found that JQFFP diminishes expression of the NF- $x \mathrm{~B}$ protein in those cells $(35 \% v$ s. control at $100 \mu \mathrm{M}$ CE) (Fig. 5A). Furthermore, at the concentration of $100 \mu \mathrm{M}$ CE, the tested JQFFP also reduced phosphorylation at serine 529 of the p65 subunit (49\% vs. control) (Fig. 5B). It should be emphasized that JQFFP not only inhibited the NF- $x \mathrm{~B}$ expression at the level of translation, but also phosphorylation of the p65 functional domain, resulting in the weakening of the transactivation potential of NF- $x \mathrm{~B}$ in those cells. Our results are in line with reports on the suppression of COX-2, MMP-9, and NF- $x$ B activation by other natural polyphenols and polyphenolrich extracts in various experimental models in both, the CRC and other cancers (Afrin et al., 2016; Shanmugam et al., 2011; Rodríguez-Ramiro et al., 2013).

\section{CONCLUSION}

Our results clearly demonstrate that Japanese quince fruit flavanol preparation reduces the SW-480 colon cancer cell viability. Importantly, JQFFP did not cause any reduction in the number of normal CCD-18Co fibroblast cells, which are an essential component in the maintenance of the intestinal mucosa. Furthermore, this is the first report to identify the inhibition of both, the COX-2 and MMP-9 expression by JQFFP, which suggests that it has anti-inflammatory and anti-invasive activities towards colon cancer cells. These anti-inflammatory, anti-invasive, and anti-proliferative effects of JQFFP are linked to reduced NF- $x \mathrm{~B}$ activation in the SW-480 cells, which is one of the significant mechanisms for the prevention of colorectal cancer. Our results indicate that JQFFP may be used as a natural source of anti-inflammatory and chemopreventive agents for CRC. Due to its natural origin, JQFFP is less likely to cause severe side effects than synthetic drugs, including NSAIDs.

\section{Conflict of interest statement}

The authors declare no conflict of interest.

\section{Acknowledgements}

We gratefully acknowledge Alicja Kucharska PhD, DSc from the Wroclaw University of Environmental and Life Sciences for determining the composition of polyphenolic compounds by UPLC-QTOF-MS.

This work was financed by the Medical University of Lodz (No. 503/1-156-04/503-01) and by the Polish Ministry of Science and Higher Education (Project No. NN 312-446-840).

\section{REFERENCES}

Afrin S, Giampieri F, Gasparrini M, Forbes-Hernandez TY, VarelaLópez A, Quiles JL, Mezzetti B, Battino M (2016) Chemopreventive and therapeutic effects of edible berries: a focus on colon cancer prevention and treatment. Molecules 21: 169. doi: 10.3390/ molecules21020169.

Arber N, Eagle CJ, Spicak J, Rácz I, Dite P, Hajer J, Zavoral M, Lechuga MJ, Gerletti P, Tang J, Rosenstein RB, Macdonald K, Bhadra P, Fowler R, Wittes J, Zauber AG, Solomon SD, Levin B (2006) PreSAP Trial Investigators. Celecoxib for the prevention of colorectal adenomatous polyps. N Engl J Med 355: 885-895. doi: 10.1056/ NEJMoa061652

Carvalho M, Silva BM, Silva R, Valentão P, Andrade PB, Bastos ML (2010) First report on Cydonia oblonga Miller anticancer potential: differential antiproliferative effect against human kidney and colon cancer cells. J Agric Food Chem 58: 3366-3370. doi: 10.1021/ jf903836k

Chen WS, Wei SJ, Liu JM, Hsiao M, Kou-Lin J, Yang WK (2001) Tumor invasiveness and liver metastasis of colon cancer cells correlated with cyclooxygenase-2 (COX-2) expression and inhibited by a COX-2-selective inhibitor, etodolac. Int J Cancer 91: 894-899. doi: 10.1002/1097-0215(200102)9999:9999<894::AIDIJC1146>3.0.CO;2-\#

Cho YB, Lee WY, Song SY, Shin HJ, Yun SH, Chun HK. ( 2007) Matrix metalloproteinase-9 activity is associated with poor prognosis in T3-T4 node-negative colorectal cancer. Hum Pathol 38: 1603-1610. doi: 10.1016/j.humpath.2007.03.018

Dias MM, Noratto G, Martino HS, Arbizu S, Peluzio Mdo C, Talcott S, Ramos AM, Mertens-Talcott SU (2014) Pro-apoptotic activities of polyphenolics from açai (Euterpe oleracea Martius) in human SW-480 colon cancer cells. Nutr Cancer 66: 1394-1405. doi: 10.1080/01635581.2014.956252

Dixon DA, Blanco FF, Bruno A, Patrignani P (2013) Mechanistic aspects of cox-2 expression in colorectal neoplasia. Recent Results Cancer Res 191: 7-37. doi:10.1007/978-3-642-30331-9_2

Gorlach S, Wagner W, Podsędek A, Szewczyk K, Koziołkiewicz M, Dastych J (2011) Procyanidins from Japanese quince (Chaenomeles ja-
ponica) fruit induce apoptosis in human colon cancer Caco-2 cells in a degree of polymerization-dependent manner. Nutr Cancer 63: 1348-1360. doi: 10.1080/01635581.2011.608480 
Ivanov AI, Parkos CA, Nusrat A (2010) Cytoskeletal regulation of epithelial barrier function during inflammation. Am J Pathol 177: 512524. doi: 10.2353 /ajpath.2010.100168

Kessenbrock K, Plaks V, Werb Z (2010) Matrix metalloproteinases: regulators of the tumor microenvironment. Cell 141: 52-67. doi: 10.1016/j.cell.2010.03.015

Kojima M, Morisaki T, Sasaki N, Nakano K, Mibu R, Tanaka M, Katano M (2004) Increased nuclear factor- $x \mathrm{~B}$ activation in human colorectal carcinoma and its correlation with tumor progression. Anticancer Res 24, 675-682

Kucharska AZ (2012) Active compounds of cornelian cherry fruit (Cornus mas L.). Publishing House of University of Wroclaw.

Lawrence T (2009) The nuclear factor NF-kappaB pathway in inflammation. Cold Spring Harb Perspect Biol 1: a001651. doi: 10.1101/cshperspect.a001651

Lewandowska U, Owczarek K, Szewczyk K, Podsędek A, Koziołkiewicz M, Hrabec E (2014) Influence of polyphenol extract from evening primrose (Oenothera paradoxa) seeds on human prostate and breast cancer cell lines. Postepy Hig Med Dosw 68: 110-118. doi: 10.5604/17322693.1088036

Lewandowska U, Szewczyk K, Owczarek K, Hrabec Z, Podsędek A, Koziołkiewicz M, Hrabec E (2013a) Flavanols from Japanese quince (Chaenomeles japonica) fruit inhibit human prostate and breast cancer cell line invasiveness and cause favorable changes in bax/ bcl-2 mRNA ratio. Nutr Cancer 65: 273-285. doi:10.1080/0163558 1.2013.749292

Lewandowska U, Szewczyk K, Owczarek K, Hrabec Z, Podsędek A, Sosnowska D, Hrabec E (2013b) Procyanidins from evening primrose (Oenothera paradoxa) defatted seeds inhibit invasiveness of breast cancer cells and modulate the expression of selected genes involved in angiogenesis, metastasis, and apoptosis. Nutr Cancer 65: 12191231. doi:10.1080/01635581.2013.830314

Li X, Yang YB, Yang Q, Sun LN, Chen WS (2009) Anti-inflammatory and analgesic activities of Chaenomeles speciosa fractions in laboratory animals. I Med Food 12: 1016-1022. doi: 10.1089/jmf.2008.1217

Mitjavila MT, Moreno JJ (2012) The effects of polyphenols on oxidative stress and the arachidonic acid cascade. Implications for the prevention/treatment of high prevalence diseases. Biochem Pharmacol 84: 1113-1122. doi: 10.1016/j.bcp.2012.07.017

Oszmiański J (1992) Method of preparation of biologically active oligomeric proanthocyanidins from plant raw materials. Polish patent No. P-296521

Park JH, McMillan DC, Horgan PG, Roxburgh CS (2014) The impact of anti-inflammatory agents on the outcome of patients with colorectal cancer. Cancer Treat Rev 40: 68-77. doi: 10.1016/j. ctrv.2013.05.006

Pfaffl MW, Horgan GW, Dempfle L (2002) Relative Expression Software Tool (REST(c)) for group wise comparison and statistical analysis of relative expression results in real-time PCR. Nucleic Acids Res 30: e36

Qian Z, Wu Z, Huang L, Qiu H, Wang L, Li L, Yao L, Kang K, Qu J, Wu Y, Luo J, Liu JJ, Yang Y, Yang W, Gou D (2015) Mulberry fruit prevents LPS-induced NF- $\varkappa \mathrm{B} / \mathrm{pERK} / \mathrm{MAPK}$ signals in macrophages and suppresses acute colitis and colorectal tumorigenesis in mice. Sci Rep 5: 17348. doi: 10.1038/srep17348

Rodríguez-Ramiro I, Ramos S, López-Oliva E, Agis-Torres A, Bravo L, Goya L, Martín MA (2013) Cocoa polyphenols prevent inflammation in the colon of azoxymethane-treated rats and in TNF- $\alpha$ stimulated Caco-2 cells. Br J Nutr 110: 206-215. doi: 10.1017/ S0007114512004862

Rösch D, Bergmann M, Knorr D, Kroh LW (2003) Structure-antioxidant efficiency relationships of phenolic compounds and their contribution to the antioxidant activity of sea buckthorn juice. J Agric Food Chem 51: 4233-4239. doi: 10.1021/jf0300339

Sałaga M, Lewandowska U, Sosnowska D, Zakrzewski PK, Cygankiewicz AI, Piechota-Polańczyk A, Sobczak M, Mosinska P, Chen C, Krajewska WM, Fichna J (2014) Polyphenol extract from evening primrose pomace alleviates experimental colitis after intracolonic and oral administration in mice. Naunyn Schmiedebergs Arch Pharmacol 387: 1069-1078. doi: 10.1007/s00210-014-1025-x

Shanmugam MK, Kannaiyan R, Sethi G (2011) Targeting cell signaling and apoptotic pathways by dietary agents: role in the prevention and treatment of cancer. Nutr Cancer 63: 161-173. doi: 10.1080/01635581.2011.523502

Shin Y, Yoon SH, Choe EY, Cho SH, Woo Ch, Rho JY, Kim JH (2007) PMA-induced up-regulation of MMP-9 is regulated by a PKCalpha-NF-kappaB cascade in human lung epithelial cells. Exp Mol Med 39: 97-105. doi: 10.1038/emm.2007.11

Steinbach G, Lynch PM, Phillips RK, Wallace MH, Hawk E, Gordon GB, Wakabayashi N, Saunders B, Shen Y, Fujimura T, Su LK, Levin B, Godio L, Patterson S, Rodriguez-Bigas MA, Jester SL, King KL, Schumacher M, Abbruzzese J, DuBois RN, Hittelman WN, Zimmerman S, Sherman JW, Kelloff G (2000) The effect of celecoxib, a cyclooxygenase- 2 inhibitor, in familial adenomatous polyposis. $N$ Engl J Med 342: 1946-1952. doi: 10.1056/NEJM200006293422603

Strek M, Gorlach S, Podsedek A, Sosnowska D, Koziolkiewicz M, Hrabec Z, Hrabec E (2007) Procyanidin oligomers from Japanese quince (Chaenomeles japonica) fruit inhibit activity of MMP-2 and MMP-9 metalloproteinases. I Agric Food Chem 55: 6447-6452. doi: $10.1021 /$ if070621c

Strugała P, Cyboran-Mikołajczyk S, Dudra A, Mizgier P, Kucharska AZ, Olejniczak T, Gabrielska J (2016) Biological activity of japanese quince extract and its interactions with lipids, erythrocyte membrane, and human albumin. J Membr Biol 249: 393-410. doi: $10.1007 / \mathrm{s} 00232-016-9877-2$

Tak PP, Firestein GS (2001) NF-kappaB: a key role in inflammatory diseases. J Clin Invest 107: 7-11. doi: 10.1172/JCI11830

Takada Y, Aggarwal BB (2003) Betulinic acid suppresses carcinogeninduced NF-kappa B activation through inhibition of I kappa B alpha kinase and p65 phosphorylation: abrogation of cyclooxygenase-2 and matrix metalloprotease-9. J Immunol 171: 3278-3286. doi: 10.4049/jimmunol.171.6.3278

Tazawa R, Xu XM, Wu KK, Wang LH (1994) Characterization of the genomic structure, chromosomal location and promoter of human prostaglandin $\mathrm{H}$ synthase-2 gene. Biochem Biophys Res Commun 203: 190-199. doi:10.1006/bbrc.1994.2167

Temraz S, Mukherji D, Shamseddine A (2013) Potential targets for colorectal cancer prevention. Int J Mol Sci 14: 17279-17303. doi: $10.3390 /$ ijms140917279

Tergaonkar V, Correa RG, Ikawa M, Verma IM (2005) Distinct roles of IkappaB proteins in regulating constitutive NF-kappaB activity. Nat Cell Biol 7: 921-923. doi: 10.1038/ncb1296

Tsujii M, Kawano S, DuBois RN (1997) Cyclooxygenase-2 expression in human colon cancer cells increases metastatic potential. Proc Natl Acad Sci U S A 94: 3336-3340

Viatour P, Merville MP, Bours V, Chariot A (2005) Phosphorylation of NF-kappaB and IkappaB proteins: implications in cancer and inflammation. Trends Biochem Sci 30: 43-52. doi: 10.1016/j. tibs.2004.11.009

Wang D, Dubois RN (2010) The role of COX-2 in intestinal inflammation and colorectal cancer. Oncogene 29: 781-788. doi: 10.1038/ onc. 2009.421

Wang D, Westerheide SD, Hanson JL, Baldwin AS Jr (2000) Tumor necrosis factor alpha-induced phosphorylation of RelA/p65 on Ser529 is controlled by casein kinase II. J Biol Chem 275: 3259232597. doi: $10.1074 /$ jbc.M001358200

Yao G, Liu C, Huo H, Liu A, Lv B, Zhang C, Wang H, Li J, Liao L (2013) Ethanol extract of Chaenomeles speciosa Nakai induces apoptosis in cancer cells and suppresses tumor growth in mice. Oncol Lett 6: 256-260. doi: 10.3892/ol.2013.1340.

Zielińska M, Lewandowska U, Podsędek A, Cygankiewicz AI, Jacenik D, Sałaga M, Kordek R, Krajewska WM, Fichna J (2015) Orally available extract from Brassica oleracea var. capitata rubra attenuates experimental colitis in mouse models of inflammatory bowel diseases. J Funct Foods 17: 587-599. doi: 10.1111/jphp.12335 